\title{
Logistics Assessment of Functional Performance of Material Flows in Railway Transport
}

\author{
Jozef Majerčák ${ }^{1, *}$, and Peter Majerčák ${ }^{2}$ \\ ${ }^{1}$ University of Žilina, Faculty of Operation and Economics of Transport and Communications, \\ Department of Railway transport, Univerzitná 1, Žilina 010 26, Slovakia \\ ${ }^{2}$ University of Žilina, Faculty of Operation and Economics of Transport and Communications, \\ Department of Economics, Univerzitná 1, Žilina 010 26, Slovakia
}

\begin{abstract}
The article includes the proposal of new methodology assessment of functional performance of material flows as a tool for management decision-making in the selection of suitable suppliers of logistical services in railway transport. This selection is based on evaluation of key indicators and determination of their weights. The evaluation of the indicators and determination of their weights is realised by mathematic methods.
\end{abstract}

\section{Introduction}

Theories about the logistics evaluation of material flow of rail transport are overlooked by all stakeholders. In Slovakia, while we try to apply foreign knowledge and search the best solutions for our region (for example methods KPI, KPD, LPI, VDA 17, MS 9000 respectively MMOG) [1-9].

\section{The proposal assessment methodology}

The methodology is conceived to be usable for any company that will need to assess the functional performance of material flow in the implementation by different suppliers based on objective indicators. The procedure we propose is depicted in the following breakdown (see Fig.1).

\footnotetext{
*Corresponding author: jozef.majercak@fpedas.uniza.sk
} 


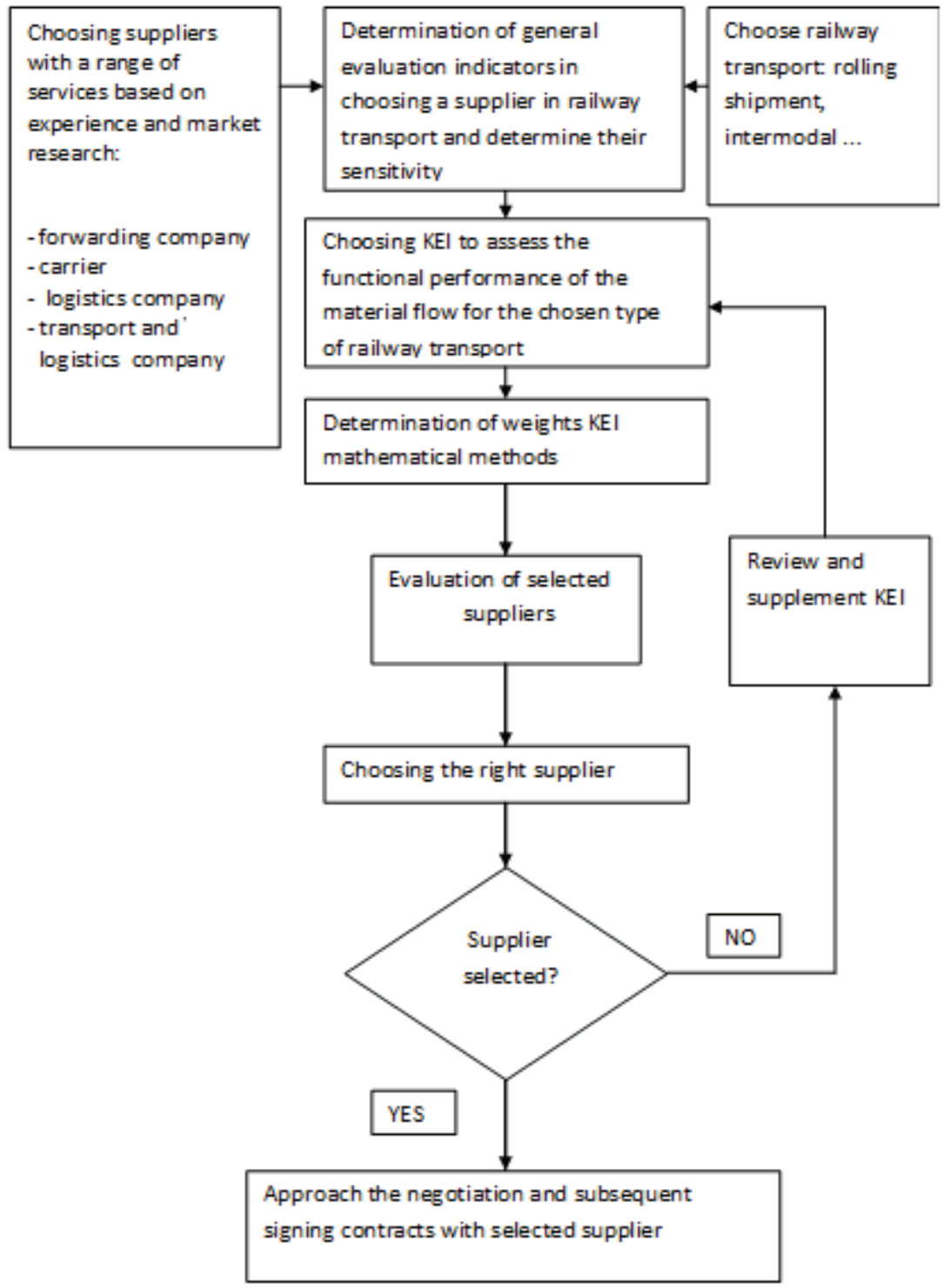

Fig. 1. The procedure for selecting the suitable supplier of logistics services in railway transport. Source: authors

\section{Determination of general evaluation indicators in choosing a supplier in railway transport}

Table 1 shows the general evaluation indicators used in daily operations. Collection of these of indicators is open and can be added at any time for new indicators. The order of indicator in the table is a random and does not prioritize the individual indicators. 
Table 1. The general evaluation indicators for choosing a supplier of railway transport. Source: authors

\begin{tabular}{|c|c|}
\hline $\begin{array}{c}\text { Order } \\
\text { (random) }\end{array}$ & General evaluation indicators \\
\hline 1. & The reliability compliance with the time of delivery (transit) \\
\hline 2. & Total transit time (from border to border) \\
\hline 3. & Total price from sender to recipient \\
\hline 4. & Quality of forwarding services \\
\hline 5. & The possibility of find shipments \\
\hline 6. & Providing regular monitoring of movement shipments \\
\hline 7. & Insurance of transported shipments \\
\hline 8. & Guarantee the protection of goods against loss, damage or breach of \\
\hline 9. & $\begin{array}{l}\text { The range and quality of services provided at the state border in railway } \\
\text { transport }\end{array}$ \\
\hline 10. & $\begin{array}{l}\text { Possibility to provide customs operations necessary for the further } \\
\text { handling of goods }\end{array}$ \\
\hline 11. & Staff qualifications and competence \\
\hline 12. & Language skills of staff \\
\hline 13. & Economic and financial stability of supplier \\
\hline 14. & The quality of the sale of services, ease to negotiate competitive prices \\
\hline 15. & $\begin{array}{l}\text { Possession of the necessary equipment. Ability to ensure the equipment } \\
\text { for handling goods }\end{array}$ \\
\hline 16. & $\begin{array}{l}\text { Ability to provide the type or kind of vehicle for further transportation - } \\
\text { such as the transshipment }\end{array}$ \\
\hline 17. & Readiness supplier negotiations on the revision services \\
\hline 18. & The complexity of the order process required services \\
\hline 19. & Readiness supplier negotiations on the revision price \\
\hline 20. & Availability of storage \\
\hline 21. & Secure store against theft \\
\hline 22. & Insurance of goods in the store \\
\hline 23. & Warehouse staff training required for handling the types of goods \\
\hline 24. & The owner of the certificate of quality ISO \\
\hline 25. & A member of FIATA \\
\hline 26. & $\begin{array}{c}\text { A member of Association of Logistics and Freight Forwarding of the } \\
\text { Slovak Republic }\end{array}$ \\
\hline 27. & $\begin{array}{l}\text { Additional services required for the treatment of goods before delivery } \\
\text { to the customer (for example, assembling packages) }\end{array}$ \\
\hline 28. & Possibility to provide palletizing goods during transshipment \\
\hline 29. & Possibility to provide strapping goods during transshipment \\
\hline 30. & Possibility to provide foiling goods during transhipment \\
\hline 31. & Possibility to provide selection of suitable wagons for loading \\
\hline 32. & Possibility to provide sorting of goods according to specified criteria \\
\hline 33. & Affinity shipment \\
\hline 34. & Supplementary criteria for supplier selection \\
\hline
\end{tabular}




\section{Determination of sensitivity for the assessment of individual indicators}

By determining the sensitivity of indicators identifies a threshold when the indicator crosses the border between the two evaluations.

Determination of the sensitivity of indicators:

a - The supplier can arrange the selected indicator accurately according to requirements without the need to use the agreed tolerances the supplier can propose new quality or costeffective solutions.

b - The supplier can arrange the selected indicator, as required by agreed tolerance without intervention of customer.

c - New supplier with good references.

$\mathrm{d}$ - The supplier can arrange the selected indicator, does not respect the agreed limits of tolerance, the intervention of the customer.

e - The supplier can arrange the selected indicator, exceeds the limits of the agreed tolerance and waits for the customer intervention, is required constant monitoring of suppliers to meet contractual obligations.

f - New customer without reference.

$\mathrm{g}$ - The supplier cannot provide the selected indicator, despite contractual obligations to the client.

\section{The selection of key indicators of evaluation and determination of their weights mathematical methods - model example}

In determining the estimated weights KEI, we used more mathematical methods:

- The order method,

- The scoring method,

- Method pairwise comparisons - Fuller method,

- Method of quantitative pairwise comparisons of indicators (Saaty's method).

We select KEI to test the procedure for assessing the functional performance of the material flows implemented by multiple vendors. From general evaluation indicators (Table 1) we choose the key evaluation indicators.

For example (KEI):

I1. - The reliability compliance with the time of delivery (transit).

I4. - Quality of forwarding services.

I5. - The possibility of find shipments.

I7. - Insurance of transported shipments.

I20. - Availability of storage.

We will consider the following order of importance, KEI: 1,4=5,7,20 which means that I1 indicator will be most important, for it will I4 and I5 indicators as important, then followed I7 and at the end of I20. The indicator that is least important.

For all the methods used to determine the weights we will be based on the same initial assumptions.

We choose weights always so that the total weight of all KEI selected for a specific model example equal to one. If the weight for the $\mathrm{i}$-th indicator I tag vi for $\mathrm{i}=1,2, \ldots \mathrm{u}$, where " $\mathrm{u}$ " is the number of indicators, then for the relationship will apply: 


$$
\begin{aligned}
& u \\
& i=1
\end{aligned}
$$

When determining the weights of indicators allocate more weight to the criterion which is important. We weight assigned to the selected indicators under the terms of the sum of weights equal to one (as stated above) or by using mathematical methods that were used for the model example.

\section{Comparison of the estimated weights for the key evaluation indicators by different methods}

In Table 2, we make a direct comparison between different methods of estimating weights. The Saaty's method the most sensitive assigns appropriate assessment of individual indicators $[10,11]$, so we decided to use the results of this method in further calculations.

Table 2. Comparison of estimated weights for KEI the various mathematical methods. Source: authors

\begin{tabular}{|c|c|c|c|c|}
\hline \multirow{2}{*}{ Indicators } & \multicolumn{3}{|c|}{ Weights indicators } \\
\cline { 2 - 5 } & $\begin{array}{c}\text { The } \\
\text { order } \\
\text { metho } \\
\text { d }\end{array}$ & $\begin{array}{c}\text { The } \\
\text { scoring } \\
\text { method }\end{array}$ & $\begin{array}{c}\text { Fuller } \\
\text { method }\end{array}$ & $\begin{array}{c}\text { Saaty's } \\
\text { method }\end{array}$ \\
\hline $\begin{array}{c}\text { I1. The reliability compliance with } \\
\text { the time of delivery (transit) }\end{array}$ & 0.33 & 0.31 & 0.40 & 0.38 \\
\hline I4. Quality of forwarding services & 0.23 & 0.25 & 0.25 & 0.22 \\
\hline $\begin{array}{c}\text { I5. The possibility of find } \\
\text { shipments }\end{array}$ & 0.23 & 0.25 & 0.25 & 0.22 \\
\hline I7. Insurance of transported & 0.14 & 0.13 & 0.10 & 0.12 \\
\hline shipments & 0.07 & 0.06 & 0.00 & 0.06 \\
\hline I20. Availability of storage & & & & \\
\hline
\end{tabular}

\section{Data collection to assess}

- Own database (experience),

- The references,

- Inquiry (agency). 


\section{Evaluation of selected key indicators}

I use for the evaluation of KEI scale ranging from 1 to 5 . The higher will be evaluation, more supplier will meet the needs of the individual KEI.

Evaluation:

5 - Meets my needs, I don't have further comments.

4 - Still meets my needs but with some minor reservations.

3 - Still meets my needs but with substantial reservations.

2 - Meets my needs minimum, but I don't have to choose, now.

1 - Totally satisfying for my needs and is unacceptable.

Assignment to the sensitivity of evaluation:

5 - a.

$4-\mathrm{b}, \mathrm{c}$.

$3-\mathrm{d}$.

$2-\mathrm{e}, \mathrm{f}$.

$1-\mathrm{g}$.

We consider about six suppliers of services in the model example [12]. We evaluated KEI for each supplier selected on experience while respecting of sensitivity assigned the evaluation.

Overall evaluation of the individual KEI for the particular supplier:

$$
C_{i, d}=v_{i} . H_{i, d}, \text { for } i=1 \text { to } u
$$

where :

$C_{i, d}$ - An overall assessment of the i-th key indicator (I) $d$-th supplier where $d=1.2 \ldots . z$ and $z$ - means of the number of suppliers.

$u \quad$ - Numbers of indicators.

$\mathrm{v}_{\mathrm{i}} \quad$ - The weight of the $i$ - th KEI.

$H_{i, d}$ - Evaluation of $i$ - th KEI,$d$ - th d supplier.

$\sum C_{i, d}$ - The sum total evaluation KEI - final evaluation $d$ - th supplier.

The supplier with the highest sum of evaluations KEI will head order suppliers and I give him 1st place [13]. A detailed overview of our assessment of suppliers Table 3 provides. 
Table 3. Evaluation of suppliers Source: authors

\begin{tabular}{|c|c|c|c|c|c|c|}
\hline & \multicolumn{5}{|c|}{ Indicators } & $\begin{array}{c}\text { The order } \\
\text { suppliers }\end{array}$ \\
\cline { 2 - 7 } & I1. & I4. & I5. & I7. & I20. & $\begin{array}{c}\text { I Ci,d - final } \\
\text { evaluation } \\
\text { suppliers }\end{array}$ \\
\hline Weight vi & 0.38 & 0.22 & 0.22 & 0.12 & 0.06 & 5 \\
\hline $\begin{array}{c}\text { Hi, evaluation } \\
\text { 1st supplier }\end{array}$ & 5 & 4 & 4 & 2 & 5 & 1. \\
\hline $\begin{array}{c}\text { Ci,d, overall } \\
\text { evaluation I }\end{array}$ & 1.90 & 0.88 & 0.88 & 0.24 & 0.30 & 4.20 \\
\hline $\begin{array}{c}\text { Hi, evaluation } \\
\text { 2nd supplier }\end{array}$ & 4 & 5 & 1 & 2 & 5 & 5. \\
\hline $\begin{array}{c}\text { Ci,d, overall } \\
\text { evaluation I }\end{array}$ & 1.52 & 1.10 & 0.22 & 0.24 & 0.30 & 3.38 \\
\hline $\begin{array}{c}\text { Hi, evaluation } \\
\text { 3rd supplier }\end{array}$ & 4 & 3 & 5 & 4 & 1 & 2. \\
\hline $\begin{array}{c}\text { Ci,d, overall } \\
\text { evaluation I }\end{array}$ & 1.52 & 0.66 & 1.10 & 0.48 & 0.06 & 3.82 \\
\hline $\begin{array}{c}\text { Hi, evaluation } \\
\text { 4th supplier }\end{array}$ & 3 & 4 & 4 & 5 & 5 & 3. \\
\hline $\begin{array}{c}\text { Ci,d, overall } \\
\text { evaluation I }\end{array}$ & 1.14 & 0.88 & 0.88 & 0.60 & 0.30 & 3.80 \\
\hline $\begin{array}{c}\text { Hi, evaluation } \\
\text { 5th supplier }\end{array}$ & 2 & 4 & 4 & 3 & 5 & 6.96 \\
\hline $\begin{array}{c}\text { Ci,d, overall } \\
\text { evaluation I }\end{array}$ & 0.76 & 0.88 & 0.88 & 0.36 & 0.30 & 3.18 \\
\hline $\begin{array}{c}\text { Hi, evaluation } \\
\text { 6th supplier }\end{array}$ & 5 & 2 & 3 & 5 & 1 & 4. \\
\hline $\begin{array}{c}\text { Ci,d, overall } \\
\text { evaluation I }\end{array}$ & 1.90 & 0.44 & 0.66 & 0.60 & 0.06 & 3.66 \\
\hline
\end{tabular}

\section{Conclusions}

In further work we will elaborate in more detail using entropic methods $[3,10]$ to determine the weights of individual indicators for cases where we do not clearly identified priorities between individual KEI. In further work we will elaborate in more detail using entropic methods $[3,10]$ for determining weights of individual KEI in cases where we do not clearly identified priorities between indicators. In this case, individual KEI assigns different probabilities. Preliminary calculations show that the process is very sensitive to the objectivity of input information, which then affects a significant degree of uncertainty (entropy) and thus the weight of the selected KEI. Higher sensitivity could this method ever closer to objective evaluation weights the key evaluation indicators (KEI).

This paper is supported by the research project "From horse-drawn railway to intermodal transport" within Visegrad Fund. 


\section{References}

1. D. Holcová, R. Pokorný, Multicriteria evaluation of variants, Available online: www.fzp.ujep.cz/ Pokornyr/01_Materialy/KREK_vkv.ppt (2010)

2. J. Královenský, J. Majerčák, Transport status in logistics (EDIS, Žilina, Slovak Republic, 2001)

3. J. Majerčák, Entropy of transport process in multimodal transport conditions, 90-96 (Eurokombi - Intermodal, 2009)

4. J. Majerčák, J. Plevko, Logistics chain evaluation using the LPI, 220-225 (Company diagnostics, controlling and logistics, 2010)

5. J. Majerčák, Supply chain in logistics chains, Available online: www.scss.sk/smpmcd/files/semestralne_projekty2/logistickastrategia podniku/zdroje/supplychain_v_lr.pdf (2011)

6. J. Majerčák, The function efectiveness of transport, Available online: www.ilogistics.cz/files/docs/efektivitaDopravy.doc (2010)

7. L. Ojala, T. Solakivi, CSCMP's Annual Global Conference (Turku School of Economics, Finland, 2009)

8. J. Piatka, Integrated managerial system and Entropy method (2008)

9. World bank, Available online:http://info.worldbank.org/etools/tradesurvey/modela.asp (2009)

10. Š. Kudláč, V. Štefancová, J. Majerčák, Procedia Engineering 187, 749-755 (2017), DOI: 10.1016/j.proeng.2017.04.433

11. J. Majerčák, Š. Kudláč, M. Panák, Transport Means 2016 - 20th International Scientific Conference, 65-70 (Kaunas University of Technology, Lithuania, 2016)

12. L. Černá, V. Zitrický, J. Daniš, Open Engineering 7, 1, 6-13 (2017), DOI: 10.1515/eng-2017-0002

13. Z. Záhumenská, J. Gašparík, 12th international scientific conference of young scientists on sustainable, modern and safe transport, 976-981 (Procedia Engineering 192, 2017) 